\title{
Effect of zinc nanoaquacitrate on the biochemical and productive parameters of the organism of rabbits
}

\author{
O. V. Boiko*, O. F. Honchar*, Y. V. Lesyk**, I. I. Kovalchuk**, B. V. Gutyj*** \\ *Cherkassy Experimental Station of Bioresources of National Academy of Agricultural Sciences of Ukraine, Cherkassy, Ukraine \\ **Institute of Animal Biology of NAAS, Lviv, Ukraine \\ ***Stepan Gzhytskyi National University of Veterinary Medicine and Biotechnologies, Lviv, Ukraine
}

Article info

Received 07.04.2020

Received in revised form 12.05 .2020

Accepted 13.05.2020

Cherkassy Experimental Station of Bioresources

of National Academy

of Agricultural Sciences

of Ukraine, Pasterivska st., 76,

Cherkassy, 18036, Ukraine.

Tel. $+38-047-231-40-52$

E-mail:bioresurs.ck@ukr.net

Institute of Animal Biology

of NAAS, V. Stus st., 38,

Lviv, 79034, Ukraine.

Tel.: +38-068-503-46-25.

E-mail:

yaroslavlesyk@inenbiol.com.ua

Stepan Gzhytskyi National

University of Veterinary

Medicine and Biotechnologies,

Pekarska st., 50,

Lviv, 79010, Ukraine.

Tel.: +38-068-136-20-54.

E-mail:bvh@ukr.ne

Boiko, O. V., Honchar, O. F., Lesyk, Y. V., Kovalchuk, I. I., \& Gutyj, B. V. (2020). Effect of zinc nanoaquacitrate on the biochemical and productive parameters of the organism of rabbits. Regulatory Mechanisms in Biosystems, 11(2), 243-248. doi:10.15421/022036

Zinc is an essential microelement for the organism of animals, and its deficiency reduces the synthesis and degradation of proteins, lipids, carbohydrates and nucleic acids, and also decreases the metabolism of vital microelements. The objective of the study was determining the effect of various amounts of zinc nanoaquacitrate on the biochemical parameters of blood and productivity of the organism of rabbits after weaning on 50th to 86th days of life. Compared with the control group, intake of zinc nanoaquacitrate by the animals of the experimental groups exhibited dose-dependent effect on separate biochemical parameters which characterize the processes of lipid and mineral metabolisms, which manifested in the increase in their content in the blood on the 12th, 24th and 36th days of the experiment. Watering rabbits with zinc citrate in the dose of $\mathrm{Zn} 0.25 \mathrm{mg} / \mathrm{kg}$ after weaning determined its physiological effect on the biochemical parameters of their organism, expressed in the most statistically reliable changes compared with other tested amounts, particularly a higher level of the total protein, increase in the activities of glutathione reductase, alanine aminotransferase, catalase and alkaline phosphatase and decrease in the levels of cholesterol, lipid hydroperoxides, compared with the control, which may indicate the positive effect of the applied additives on certain biochemical parameters of the rabbits' organism. Additional use of zinc citrate in the dose of $0.50 \mathrm{mg} / \mathrm{kg}$ of body weight was manifested in their blood by significant increase in the activities of catalase and glutathione reductase, lower level of lipid hydroperoxides and increase in the organism's growth parameter by $3.1 \%$ in the final period of the study. Watering zinc citrate in the amount of $0.75 \mathrm{mg} / \mathrm{kg}$ of body weight provoked probable decrease in the level of cholesterol and triacylglycerols and increases in catalase and glutathione reductase, increase in activity of alanine aminotrasferase and decrease in lipid hydroperoxides, which determined the stimulating effect on the growth of the organism with $8.4 \%$ higher total gain of body weight after 36 days of the experiment. From a general perspective, the research indicates that intake of lowest amount of zinc citrate was characterized by the greatest effect on the biochemical blood parameters, whereas the use of greater amounts of organic compound of zinc showed positive effect on the processes of growth and development of the organism of rabbits after weaning. Of practical importance is the study of the effect of watering zinc nanoaquacitrate in the physiologically substantiated amounts on biochemical blood parameters and growth and survivability of the offspring and organism of the mother rabbit in the period of lactation.

Keywords: antioxidant system; peroxidation of lipids; aminotransferase; microelements; proteins; lipids.

\section{Introduction}

In the diet of rabbits, microelements are important component of a number of metabolic processes and physiological functions of their organism (Darmohray et al., 2019). Zinc is a necessary microelement for humans, animals, plants and microbes, and over the last decade was broadly studied to determine its physiological and biochemical functions. In the organism of animals, zinc is a constituent of over 300 enzymes which participate in synthesis and degradation of proteins, lipids, carbohydrates and nucleic acids, and also other microelements involved in metabolism (Saleh et al., 2018). It performs the function of co-factors of enzymes (Grosskopf et al., 2017). In physiological amounts in the organisms of humans and animals, zinc affects the regulation of acid-base homeostasis and activation of metabolism. Moreover, it is a necessary component of superoxide dismutase enzyme, which performs a vital function in the system of antioxidant protection of the organism (Ivanišinová et al., 2016). Zinc plays an important role in the transcription of polynucleotides and expression of genes of cells, has an effect on the activation of factors of humoral and cellular immunity (Hassan et al., 2017). Research has revealed that physiological amounts of zinc for rabbits are within broad range of 25-60 mg/kg, the requirements for it change depending on the physiological condition of the organism. In particular, young and pregnant animals have greater need for it (Mateos et al., 2010; Wang et al., 2012). However, higher levels of zinc in the diet than are necessary for the fulfillment of the needs of the rabbits' organism may cause toxicoses in young animals, death of offspring and pregnant animals and have negative impact on the environment, therefore the use of novel compounds of microelements in nano-sized amounts is promising (Amen \& Daraji, 2011; Raguvaran et al., 2015).

Currently, nanothechnologies using compounds of mineral substances are broadly used in various spheres, including agriculture, livestock farming and industry (Albanese et al., 2012). An important direction of nanotechnologies is studying the interactions of nanomaterials and biological systems known as nano-biological interactions (Swain et al., 2016). Nano-sized particles have a greater potential for interaction due to increase in their surface, therefore their digestion, than their usual mineral salts, 
which could reduce their necessary amount in the animals' diet. The conducted surveys revealed that watering young rabbits with nano $\mathrm{Si}$ in the doses of respectively 25,50 and $75 \mu \mathrm{g}$ of Si/kg of body weight and sodium metasilicate in the amount of $2.5 \mathrm{mg}$ of Si/kg of body weight contributed to positive activation of biochemical processes in the blood. Application of nano $\mathrm{Si}$ in the amount of $50 \mu \mathrm{g}$ of Si/kg of body weight and sodium metasilicate in the amount of $2.5 \mathrm{mg} \mathrm{Si} / \mathrm{kg}$ of body weight in the diet of pregnant and lactating rabbit mothers increased the amount of erythrocytes, leukocytes and the concentration of hemoglobin and contributed to higher hematological parameters within the norm (Lesyk et al., 2020). The research confirmed the dose-dependent effect of compound of nano zinc on the growth parameters of cattle and poultry (Sri Sindhura et al., 2014), though there are very little number of such studies on young rabbits and mother rabbits in the period of physiological load. Recent studies showed that nano particles of mineral elements have higher catalytic efficiency and greater adsorbing property (Tsai et al., 2016). Furthermore, compared with their mineral salts, nanoaquachelates of microelements are easily digested in the digestive tract and take part in metabolism more efficiently, thus affecting the course of biochemical processes of the organism (Swain et al., 2015). Therefore, the objective of this study was determining the effect of zinc nanoaquacitrate on the biochemical and productive parameters of the organism of rabbits.

\section{Materials and methods}

The work was performed on 16 rabbits 40 days of age, which were kept in standard vivarium of the Institute of Animal Biology of NAAS. All manipulations with experimental animals were carried out in compliance with the rules of the European Convention for the Protection of Vertebrate Animals (Official Journal of the European Union L276/33, 2010). The experimental animals were divided into 4 groups of 4 animals each. Animals of the experimental groups were fed zinc nanoaquacitrate during the day, at a rate of $0.25,0.50$ and $0.75 \mathrm{mg}$ of $\mathrm{Zn} / \mathrm{kg}$ body weight respectively. More research materials are described in the article (Boiko et al., 2020).

In the experimental period, samples of blood were taken from marginal ear vein of animals for the assay on total protein determined using biuret test when cuprum ions in alkaline environment interact with peptide connections of proteins of blood serum with formation of complex stained in violet colour (biuret reaction), optical density of which at $540 \mathrm{~nm}$ is directly proportional to the concentration of the total protein in blood serum; activities of aspartate- and alanine- aminotransferase were determined with addition of 2,4-dinitrophenylhydrazine solution and kept $20 \mathrm{~min}$ at room temperature, to the incubatory solution we added $0.4 \mathrm{~N}$ solution of sodium hydroxide, the determining was performed on a photoelectrocolorimeter at the wavelength of $540 \mathrm{~nm}$; lipid hydroperoxides were determined as follows: $1.5 \mathrm{~mL}$ of ethanol extract was adjusted to $2.7 \mathrm{~mL}$ using ethanol, shaken and $0.02 \mathrm{~mL}$ of concentrated $\mathrm{HCI}$ and $0.03 \mathrm{~mL} 1 \%$ solution of Mohr's salt in 3\% HCI solution were added. The content was shaken and after $30 \mathrm{~s} 0.2 \mathrm{~mL}$ of $20 \%$ solution of ammonium thiocyanate was added, after which a raspberry-coloured medium was formed. The optical density was measured during $10 \mathrm{~min}$ after addition of ammonium thiocyanate on spectrophotometer at wavelength of $\lambda=$ $480 \mathrm{~nm}$; the activity of catalase was determined by adding $0.1 \mathrm{~mL}$ of erythrocyte hemolysis $(1: 10)$ and $2 \mathrm{~mL}$ of $0.03 \%$ solution of hydrogen peroxide to the experimental test tube. In the control group, instead of hemolysis, $1 \mathrm{~mL}$ of $4 \%$ solution of ammonium orthomolybdate and $2 \mathrm{~mL}$ of $0.03 \%$ solution of hydrogen peroxide were added. The incubation lasted for $10 \mathrm{~min}$ and $1 \mathrm{~mL}$ of $0.25 \mathrm{~N} \mathrm{H}_{2} \mathrm{SO}_{4}$ was added. Then, $1 \mathrm{~mL}$ of ammonium orthomolybdate was added to the test tube, and $0.1 \mathrm{~mL}$ of hemolysis to the control. Centrifugation lasted for $5 \mathrm{~min}$ at 3,000 rpm. Intensity of staining was measured on spectrophotometer at wavelength of $\lambda=410 \mathrm{~nm}$; activity of superoxide dismutase was determined according to the level of inhibition of enzymatic process by the reduction of nitro blue tetrazolium and presence of NADH and phenazine methosulfate. To determine the activity of superoxide dismutase, the erythrocytes were rinsed from the plasma of blood with normal saline, at the temperature of $4^{\circ} \mathrm{C}$. Hemoglobin was settled using a mixture of alcohol and chloroform. For this purpose, to $0.1 \mathrm{~mL}$ of erythrocytes, prior hemolysed and dis- solved 10 times in $5 \mathrm{~m}$ of Tris $\mathrm{HCl}$ (pH 7.4), we added $0.5 \mathrm{~mL}$ of ethanol and $0.3 \mathrm{~mL}$ of chloroform. The mixing and centrifugation lasted for $15 \mathrm{~min}$ at $7000-8000 \mathrm{rpm}$. The activity of superoxide dismutase was determined in supernatant liquid. The incubational mixture contained $1 \mu \mathrm{L}$ of EDTA, $1 \mathrm{mg}$ of gelatin, $0.407 \mathrm{mM}$ of nitro blue tetrazolium (NBT), $1.8 \mu \mathrm{mol} / \mathrm{L}$ of phenazine meta sulphate (PMS), $0.1 \mathrm{~mL}$ of $1 \mathrm{MM}$ $\mathrm{NADH}$. Supernatant was added into the incubational mixture in the amount of $0.1 \mathrm{~mL}$, causing slowing in the reduction of nitro blue tetrazolium. The total amount of the incubational mixture was adjusted to $3 \mathrm{~mL}$ using phosphate buffer $(0.15 \mathrm{M}, \mathrm{pH} 7.8)$. The control samples comprised the same components, except supernatant, instead of which an adequate amount of the buffer was added. The reaction was triggered by adding $0.1 \mathrm{~mL}$ of NADH to the experimental and control samples. The incubation was made for $10 \mathrm{~min}$ in the dark at room temperature. The optical density of the experimental and control samples was determined on the spectrophotometer at the wavelength of $\lambda=540 \mathrm{~nm}$; the activity of alkaline phosphatase, concentrations of cholesterol, triacylglycerols, calcium, phosphorus in the blood plasma were determined using the standard sets manufactured by Lachema company (Czech Republic); alkaline phosphatase was determined under the effect of blood serum enzyme sodium para-nitrophenyl phosphate which is hydrolyzed with subsequent formation of phosphorus and para-nitrophenol. According to its amount, the activity of enzyme is determined; cholesterol was determined after its enzymatic hydrolysis and oxidation. Quinoneimine, the indicator substance used to determine cholesterol - is formed with hydrogen peroxide and 4-aminophenazone in the presence of phenol and peroxidase; triacylglycerols were identified after their enzymatic hydrolysis by lipases according to the amount of quinoneimine formed with 4-aminoantipyrine, 4-chlorophenol and hydrogen peroxide under the influence of peroxidase; the principle of the method of determining the content of the total calcium is based on the fact that ortho-cresol phthalic complexone in alkaline medium forms a complex of reddish-violet colour with calcium, the intensity of colour of which is proportional to the calcium concentration. To the reaction mixture, 8-hydroxyquinoline was added, which binds other metals which hinder the identification, but forms a less strong complex with calcium than ortho-cresol phthalic complexone. The intensity of its colour is proportional to the concentration of the total calcium in the sample, the principle of the method of identification of non-organic phosphorus in blood plasma is based on the fact that in acidic environments phosphate ions form a complex with molybdate. The absorption of the complex of ultraviolet radiation was directly proportional to the concentration of phosphate. Absorption of the samples linearly depends on the concentration of phosphorus to $200 \mathrm{mg} / \mathrm{L}$ (Vlislo, 2012). During the research, we weighed the animals and assessed their weight increments depending on the period of the experiment according to the method in the guide (Vlislo, 2012).

The mathematical processing of the research results was worked out statistically using a program package Statistica 6.0 software (Stat Soft, Tulsa, USA). The significance of the difference between controls and treatments were evaluated using ANOVA (taking into account Bonferroni correction); differences were considered significant at $\mathrm{P}<0.05$.

\section{Results}

The content of total protein in blood of rabbits of the experimental groups compared with the control in the preparation period did not undergo any significant changes (Table 1), whereas in the blood of rabbits of the I experimental group the level of total protein was respectively higher by $14.5 \%$ and $14.0 \%(\mathrm{P}<0.05)$ on the 12 th and 36 th days of the study compared with the control. It should be noted that the content of total protein was higher in the blood of the animals of the II and III experimental groups, but the obtained differences were not probable during the experiment. Watering rabbits after weaning with zinc citrate in their diet was accompanied with changes in the activity of alanine- and aspartateaminotransferases in the blood of the experimental groups compared with the control. This manifested in reliable increase in the activity of alanine aminotransferase in the blood of animals of the I experimental group by $34.7 \%(\mathrm{P}<0.05)$ on the 24 th day and by $19.6 \%$ in the III group on the 36th day of the experiment, compared with the control. In the blood of rabbits of the II experimental group, the content of alanine aminotransfe- 
rase was not significantly altered, and was even lower than the control, which may suggest dose-dependent effect of zinc citrate on the activity of aminotransferase. In particular, activity of aspartate aminotrasferase in the blood of rabbits was not significant, having a tendency towards increase or decrease in all the experimental groups compared with the control in the course of the experiment.

\section{Table 1}

Content of total protein and enzymes in blood of rabbits during intake of different amounts of zinc citrate $(x \pm S E, n=4)$

\begin{tabular}{|c|c|c|c|c|c|}
\hline \multirow{3}{*}{ Parameter } & \multirow{3}{*}{ Group } & \multicolumn{4}{|c|}{ Period of study } \\
\hline & & \multirow{2}{*}{$\begin{array}{l}\text { preparation, } \\
50^{\text {th }} \text { day of life }\end{array}$} & \multicolumn{3}{|c|}{ experimental (day of life/day of the survey) } \\
\hline & & & $62 / 12$ & $74 / 24$ & $86 / 36$ \\
\hline \multirow{4}{*}{$\begin{array}{l}\text { Total } \\
\text { protein, } \mathrm{g} / \mathrm{L}\end{array}$} & $\mathrm{C}$ & $55.3 \pm 2.2$ & $54.2 \pm 2.9$ & $56.7 \pm 2.9$ & $56.9 \pm 2.2$ \\
\hline & I & $53.6 \pm$ & $62.1 \pm 1.7^{*}$ & $59.5 \pm 2.1$ & $64.9 \pm 1.4^{*}$ \\
\hline & II & $58.1 \pm 1.3$ & $62.2 \pm 3.9$ & $56.9 \pm 0.7$ & $63.9 \pm 3.1$ \\
\hline & III & 54.5 & $56.7 \pm 3.3$ & $54.4 \pm 2.6$ & $62.6 \pm 3.6$ \\
\hline \multirow{4}{*}{$\begin{array}{l}\text { Aspartate } \\
\text { aminotrans- } \\
\text { ferase, U/L }\end{array}$} & $\mathrm{C}$ & $25.3 \pm 2.2$ & $26.2 \pm 3.5$ & $22.6 \pm 3.2$ & 26.8 \\
\hline & I & $25.0 \pm 0.2$ & $29.4 \pm 2.8$ & $21.8 \pm 2.3$ & $22.5 \pm 4.0$ \\
\hline & II & $22.3 \pm$ & $22.5 \pm 0.9$ & $20.4 \pm 1.5$ & $23.9 \pm 1.1$ \\
\hline & III & $24.5 \pm 1.9$ & $26.9 \pm 2.1$ & $19.5 \pm 2.9$ & $25.6 \pm 2.5$ \\
\hline \multirow{4}{*}{$\begin{array}{l}\text { Alanine } \\
\text { aminotrans- } \\
\text { ferase, U/L }\end{array}$} & $\mathrm{C}$ & $43.0 \pm$ & $41.0 \pm 2.5$ & $42.0 \pm 3.8$ & $44.3 \pm 1.5$ \\
\hline & $\mathrm{I}$ & $45.0 \pm 0.1$ & $46.7 \pm 2.9$ & $56.6 \pm 3.3^{*}$ & $50.4 \pm 5.5$ \\
\hline & II & $42.3 \pm 1.4$ & $46.4 \pm 1.2$ & $50.6 \pm 2.3$ & $43.7 \pm 1.0$ \\
\hline & III & $44.6 \pm 1.2$ & $49.0 \pm 2.6$ & $43.1 \pm 3.0$ & $53.0 \pm 1.8^{*}$ \\
\hline \multirow{4}{*}{$\begin{array}{l}\text { Alkaline } \\
\text { phospha- } \\
\text { tase, U/L }\end{array}$} & $\mathrm{C}$ & $441 \pm 20$ & $407 \pm 34$ & $379 \pm 63$ & $312 \pm 13$ \\
\hline & I & $403 \pm 22$ & $365 \pm 32$ & $368 \pm 22$ & $393 \pm 16^{*}$ \\
\hline & II & $391 \pm 15$ & $442 \pm 39$ & $341 \pm 56$ & $340 \pm 16$ \\
\hline & III & $410 \pm 20$ & $378 \pm 38$ & $334 \pm 57$ & $340 \pm 16$ \\
\hline \multirow{4}{*}{$\begin{array}{l}\text { Urea, } \\
\mathrm{mmol} / \mathrm{L}\end{array}$} & $\mathrm{C}$ & $7.47 \pm 0.28$ & $5.17 \pm 0.88$ & $5.70 \pm 0.80$ & $5.23 \pm 0.47$ \\
\hline & I & $7.46 \pm 0.21$ & $6.35 \pm 0.61$ & $5.80 \pm 0.33$ & $6.43 \pm 0.36$ \\
\hline & II & $7.61 \pm 0.52$ & $6.10 \pm 0.43$ & $5.25 \pm 0.37$ & $6.70 \pm 0.62$ \\
\hline & III & $7.02 \pm 0.36$ & $4.68 \pm 0.45$ & $4.80 \pm 0.41$ & $6.65 \pm 0.48$ \\
\hline
\end{tabular}

Note: in this and the following tables the statistically significant differences were considered compared to the control group: * $-\mathrm{P}<0.05$, ** $-\mathrm{P}<0.01$, *** $-\mathrm{P}<$ 0.001 ; the selections were compared within one line (taking into account Bonferroni correction).

Watering rabbits after weaning with nano-zinc supplement manifestted in blood of the I experimental group by $25.7 \%$ increased activity of alkaline phosphatase on the 36th day of the study compared with the control. The research revealed a tendency towards changes in the level of urea, increase or decrease in other experimental groups, though their content was not significant compared to the control.

Providing rabbits with different amounts of zinc citrate during the 36 days of the research had a positive effect on the parameters of lipid metabolism in the young animals, expressed at the second and third stage of the survey (Table 2). Thus, the cholesterol content in blood of rabbits of the I and III experimental groups was respectively lower by $71.3 \%(\mathrm{P}<$ $0.05)$ and $62.3 \%(\mathrm{P}<0.001)$ on the 24 th day of experiment in the context of tendential changes on the 12th and 36th days, as compared to the control.

Content of triacylglycerols in the blood of rabbits of the III experimental group was higher by $35.7 \%$ on the 24 th day and higher by $52.6 \%$ in the II group on the 36th day of the survey compared with the control group. The content of creatinine in the blood underwent no significant changes and was within the physiological values for rabbits, as indicated by the physiological metabolic processes in the organism and absence of negative effect from the applied supplements.

The results of the conducted studies indicate that the level of lipid hydroperoxides in blood plasma of rabbits before the experiment accounted on average for $1.13 \mathrm{OD}$ unit/mL (Table 3 ).

On the 12th day since the beginning of watering with organic compound of zinc citrate, the content of lipid hydroperoxides in blood of rabbits underwent no changes, whereas in rabbits of the II experimental group it decreased by $24.3 \%(\mathrm{P}<0.05)$ on the 24 th day of the study compared with the control. It should be noted that significant changes were seen during long intake of different amounts of the surveyed substance. Particularly, in blood of animals of the I, II and III experimental groups, the level of lipid hydroperoxides was respectively lower by $22.0 \%, 17.6 \%$ and $38.2 \%$ $(\mathrm{P}<0.001)$ on the 36th day of the study compared with the control group.
Table 2

Separate parameters of lipid metabolism in the organism of rabbits during intake of different amounts of zinc citrate $(x \pm S E, n=4)$

\begin{tabular}{|c|c|c|c|c|c|}
\hline \multirow{3}{*}{$\begin{array}{c}\text { Parame- } \\
\text { ter }\end{array}$} & \multirow{3}{*}{ Group } & \multicolumn{4}{|c|}{ Periods of survey } \\
\hline & & \multirow{2}{*}{$\begin{array}{l}\text { preparation, } \\
50^{\text {th }} \text { day of life }\end{array}$} & \multicolumn{3}{|c|}{ experimental (day of life/day of survey) } \\
\hline & & & $62 / 12$ & $74 / 24$ & $86 / 36$ \\
\hline \multirow{4}{*}{$\begin{array}{l}\text { Choles- } \\
\text { terol, } \\
\mathrm{mmol} / \mathrm{L}\end{array}$} & $\mathrm{C}$ & $1.34 \pm 0.10$ & $1.14 \pm 0.06$ & $1.99 \pm 0.08$ & $1.66 \pm 0.35$ \\
\hline & I & $1.26=$ & $1.07 \pm 0.18$ & $1.42 \pm 0.11^{* *}$ & .31 \\
\hline & II & $0.98 \pm 0.62$ & $1.18 \pm 0.26$ & $1.66 \pm 0.21$ & $1.52 \pm 0.20$ \\
\hline & III & $1.02=$ & $0.97 \pm 0.09$ & $1.24 \pm 0.09 * * *$ & $1.40 \pm 0.16$ \\
\hline \multirow{4}{*}{$\begin{array}{l}\text { Triacyl- } \\
\text { glycerols, } \\
\mathrm{mmol} / \mathrm{L}\end{array}$} & $\mathrm{C}$ & & 26 & & \\
\hline & I & $0.86 \pm$ & $0.78 \pm 0.09$ & $0.14 \pm 0.74$ & $0.74 \pm 0.09$ \\
\hline & II & $0.98 \pm 0.66$ & $1.46 \pm 0.10$ & $1.10 \pm 0.20$ & $1.42 \pm 0.09^{*}$ \\
\hline & III & $1.12 \pm$ & $0.75 \pm 0.03$ & $0.95 \pm 0.08^{*}$ & $1.02 \pm 0.23$ \\
\hline \multirow{4}{*}{$\begin{array}{l}\text { Creati- } \\
\text { nine, } \\
\mu \mathrm{mol} / \mathrm{L}\end{array}$} & $\mathrm{C}$ & 82.8 & $110.0 \pm 6.4$ & $112.3 \pm 5.9$ & $109.5 \pm 2.6$ \\
\hline & I & $80.1 \pm$ & $114.8 \pm 1.5$ & $118.2 \pm 2.4$ & $114.8 \pm 2.6$ \\
\hline & II & $78.5 \pm 1.4$ & $104.3 \pm 1.5$ & $118.4 \pm 0.8$ & $103.7 \pm 2.7$ \\
\hline & III & $77.2 \pm 2.5$ & $111.8 \pm 2.4$ & $114.4 \pm 2.8$ & $106.2 \pm 3.5$ \\
\hline
\end{tabular}

Table 3

Activity of the antioxidant system in the parameters during

intake of different amounts of zinc citrate $(x \pm S E, n=4)$

\begin{tabular}{lccccc}
\hline & & \multicolumn{4}{c}{ Periods of the survey } \\
\cline { 3 - 6 } Parameter & Group & preparation, & \multicolumn{2}{c}{ Experimental (day of life/day of the survey) } \\
& & $50^{\text {th }}$ day of life & $62 / 12$ & $74 / 24$ & $86 / 36$ \\
\hline Lipid hyd- & C & $1.02 \pm 0.19$ & $0.42 \pm 0.07$ & $0.42 \pm 0.03$ & $0.68 \pm 0.03$ \\
roperoxides, & I & $1.04 \pm 0.11$ & $0.51 \pm 0.04$ & $0.36 \pm 0.02$ & $0.15 \pm 0.01^{* * *}$ \\
OD & II & $1.26 \pm 0.01$ & $0.50 \pm 0.16$ & $0.32 \pm 0.02^{*}$ & $0.12 \pm 0.03^{* * *}$ \\
units/mL & III & $1.23 \pm 0.23$ & $0.49 \pm 0.05$ & $0.43 \pm 0.11$ & $0.26 \pm 0.03^{* * *}$ \\
\hline Catalase, & C & $8.1 \pm 0.4$ & $4.7 \pm 0.8$ & $10.2 \pm 0.5$ & $11.3 \pm 0.1$ \\
$\mu$ mol/min $\times$ & I & $7.5 \pm 0.6$ & $4.5 \pm 0.4$ & $9.6 \pm 0.4$ & $12.8 \pm 0.1 * * *$ \\
mg of & II & $9.5 \pm 0.6$ & $4.8 \pm 0.5$ & $5.7 \pm 0.3 * * *$ & $13.4 \pm 0.8$ \\
protein & III & $6.8 \pm 0.4$ & $4.2 \pm 0.3$ & $6.8 \pm 0.3 * * *$ & $11.1 \pm 0.3$ \\
\hline & C & $0.96 \pm 0.02$ & $1.67 \pm 0.13$ & $1.56 \pm 0.12$ & $1.55 \pm 0.22$ \\
Glutathione & I & $1.03 \pm 0.08$ & $1.41 \pm 0.08$ & $2.90 \pm$ & $1.31 \pm 0.31$ \\
reductase & & & & $0.24^{* *}$ & \\
$\mu$ Mmol/min $\times$ & II & $0.89 \pm 0.01$ & $1.24 \pm 0.14$ & $3.18 \pm$ & $2.29 \pm 0.34$ \\
mg protein & & & & $0.32^{* *}$ & \\
& III & $0.96 \pm 0.02$ & $1.88 \pm 0.34$ & $3.02 \pm$ & $1.79 \pm 0.25$ \\
\hline
\end{tabular}

It was determined that the activity of catalase in blood of rabbits before the the experiment equaled on average $7.99 \mathrm{mmol} / \mathrm{min} \times \mathrm{mg}$ of protein. On the 12th day of the studies, the activity of catalase in blood of animals reliably did not change, while on the 24th day from the beginning of the surveys the activity of catalase reliably decreased by $43.6 \%$ in blood of rabbits of the II experimental group by $32.9 \%$ in the III experimental group compared with the control. Also, we noted a tendency towards decrease in the activity of catalase in blood of animals of the I experimental group. On the 36th day of the experiment, activity of catalase reliably increased in the in blood of rabbits of the I experimental group by $12.7 \%(\mathrm{P}<0.001)$ compared with the control group. Furthermore, a tendency towards increase in the activity of the enzyme in the II experimental group was observed.

As a result of the conducted surveys, we determined that the activity of glutathione reductase in the blood of rabbits before the experiment accounted for $0.96 \mu \mathrm{mol} / \mathrm{min} \times \mathrm{mg}$ of protein. On the 12 th day from the beginning of the experiment the activity of glutathione reductase in the blood of animals of the experimental groups was observed to tend to decrease. On the 24th day of intake of different amounts of zinc citrate, in the blood of rabbits of the I, II and III experimental groups, the activity of glutathione reductase was reliably higher $(\mathrm{P}<0.01)$ compared with the control, whereas at the final stage of the study, no reliable differences between the control and experimental groups of animals were seen. Increase in the activity of glutathione reductase in the blood of rabbits consuming nanocompounds indicates their positive effect on the enzymic reduction of glutathione.

Watering rabbits during the survey with different amounts of zinc citrate was accompanied by tendential changes in the level of calcium and phosphorus in the blood plasma of rabbits of the experimental groups compared with the control, which were within the physiological values 
(Table 4). The research revealed that in the preparation period, on the 50th day of life of the rabbits, the ratio of calcium and phosphorus was within 2.21-2.53:1, indicating excess of calcium in the diet of animals and thus its increased content in the blood, which reduces the digestibility of phosphorus in the organism. However, the use of different amounts of zinc citrate over 36 days contributed to the normalization of the ratio between calcium and phosphorus in animals of the I-III experimental groups, ranging within the determined parameters accounting for 1.22-1.72: 1 .

The results of the studies exhibited the superiority in the intensity of growth of rabbits of the experimental groups compared with the control (Table 5). Therefore, on the 50th day of life the animals of the experimental groups in comparison with the control were observed to have insignificant increments in body weight, whereas at the final stage of the experiment the total increment of body weight of the I, II and III experimental groups were higher than the control respectively by $1.3 \%, 3.1 \%$ and $8.4 \%$.

The obtained results of the total increment in the body weight of rabbits of the experimental groups in comparison with the control correlated with their body weight and average daily increment. For the indicated period of the study, the animals of the I, II and III experimental groups were observed to have average daily increment respectively equaling $1.4 \%, 3.2 \%$ and $8.5 \%$ compared with the control. The surveys revealed intensification of the processes of protein metabolism under the effect of the different amounts of the supplement, which was more manifested during intake of the highest tested amount in the diet of young rabbits after weaning.

\section{Table 4}

Content of calcium and phosphorus and their ratio in blood of rabbits which intake different amounts of zinc citrate $(x \pm S E, n=4)$

\begin{tabular}{|c|c|c|c|c|c|}
\hline \multirow{3}{*}{ Parameter } & \multirow{3}{*}{ Group } & \multicolumn{4}{|c|}{ Periods of survey } \\
\hline & & \multirow{2}{*}{$\begin{array}{l}\text { preparation, } \\
50^{\text {th }} \text { day of life }\end{array}$} & \multicolumn{3}{|c|}{ experimental (day of life/day of the experiment) } \\
\hline & & & $62 / 12$ & $74 / 24$ & $86 / 36$ \\
\hline \multirow{4}{*}{$\begin{array}{l}\text { Total } \\
\text { calcium, } \\
\mathrm{mmol} / \mathrm{L}\end{array}$} & $\mathrm{C}$ & $3.23 \pm 0.13$ & $2.57 \pm 0.15$ & $2.63 \pm 0.15$ & $2.78 \pm 0.10$ \\
\hline & I & $3.30 \pm 0.15$ & $2.60 \pm 0.13$ & $2.93 \pm 0.17$ & $2.88 \pm 0.08$ \\
\hline & II & $3.13 \pm 0.15$ & $2.53 \pm 0.12$ & $2.40 \pm 0.07$ & $2.87 \pm 0.18$ \\
\hline & III & $3.30 \pm 0.17$ & $2.50 \pm 0.04$ & $2.38 \pm 0.11$ & $2.88 \pm 0.13$ \\
\hline \multirow{4}{*}{$\begin{array}{l}\text { Non- } \\
\text { organic } \\
\text { phosphorus, } \\
\text { mmol/L }\end{array}$} & $\mathrm{C}$ & $1.46 \pm 0.12$ & $1.95 \pm 0.28$ & $1.87 \pm 0.32$ & $2.15 \pm 0.13$ \\
\hline & I & $1.36 \pm 0.12$ & $1.82 \pm 0.21$ & $1.70 \pm 0.16$ & $2.10 \pm 0.16$ \\
\hline & II & $1.36 \pm 0.09$ & $1.90 \pm 0.19$ & $1.80 \pm 0.27$ & $2.47 \pm 0.09$ \\
\hline & III & $1.30 \pm 0.15$ & $1.75 \pm 0.24$ & $1.95 \pm 0.10$ & $2.08 \pm 0.12$ \\
\hline \multirow{4}{*}{$\begin{array}{l}\text { Calcium: } \\
\text { Phosphorus }\end{array}$} & $\mathrm{C}$ & $2.21: 1$ & $1.31: 1$ & $1.40: 1$ & $1.29: 1$ \\
\hline & I & $2.42: 1$ & $1.42: 1$ & $1.72: 1$ & $1.37: 1$ \\
\hline & II & $2.30: 1$ & $1.33: 1$ & $1.33: 1$ & $1.16: 1$ \\
\hline & III & $2.53: 1$ & $1.42: 1$ & $1.22: 1$ & $1.38: 1$ \\
\hline
\end{tabular}

Table 5

Growth of the organism of rabbits during intake of different amounts of zinc citrate $(x \pm S E, n=4)$

\begin{tabular}{|c|c|c|c|c|c|c|}
\hline \multirow{2}{*}{$\begin{array}{c}\text { Group } \\
\text { of animals }\end{array}$} & \multicolumn{3}{|c|}{ Preparation period, $50^{\text {th }}$ day of life } & \multicolumn{3}{|c|}{ Experimental period, $86^{\text {th }}$ day of life } \\
\hline & body weight, $g$ & body weight increment, $g$ & average daily increment, $\mathrm{g}$ & body weight, $g$ & body weight increment, $\mathrm{g}$ & average daily increment, $g$ \\
\hline $\mathrm{C}$ & $1431 \pm 117$ & $1371 \pm 127$ & $27.3 \pm 2.5$ & $2655 \pm 122$ & $1227 \pm 50$ & $33.9 \pm 1.4$ \\
\hline I & $1465 \pm 102$ & $1405 \pm 102$ & $28.0 \pm 2.0$ & $2705 \pm 196$ & $1240 \pm 222$ & $34.4 \pm 6.2$ \\
\hline$\%$ to $\mathrm{C}$ & 102.3 & 102.5 & 102.5 & 101.8 & 101.3 & 101.4 \\
\hline II & $1306 \pm 85$ & $1246 \pm 85$ & $24.8 \pm 1.7$ & $2569 \pm 137$ & $1263 \pm 59$ & $35.0 \pm 1.7$ \\
\hline$\%$ to $\mathrm{C}$ & 91.2 & 90.8 & 90.8 & 96.7 & 103.1 & 103.2 \\
\hline III & $1358 \pm 84$ & $1297 \pm 84$ & $25.9 \pm 1.7$ & $2685 \pm 17$ & $1328 \pm 76$ & $36.8 \pm 2.1$ \\
\hline$\%$ to $\mathrm{C}$ & 94.8 & 94.6 & 94.8 & 101.1 & 108.4 & 108.5 \\
\hline
\end{tabular}

\section{Discussion}

Intake of different amounts of zinc citrate affected the content of the total protein and activity of amino transferases in the blood of rabbits of the experimental groups compared with the control which were within the physiological values throughout the study. It has to be noted that the greatest effect was exerted on the content of total protein and activity of enzymes alanine transferases, alkaline phosphatase in animals that consumed the smallest amount of zinc citrate.

Enzymes are biological catalysers which enhance the metabolic processes in cell cytoplasm. They continuously synthesize in blood cells and penetrate the blood current. Enzymes are characteristic of localizing in the corresponding cells and their structural elements (cytoplasm, mitochondria, nucleus). In cases of excessive penetrability of the cellular membrane the enzymes penetrate blood and create increased activity (hyperenzemia) in it (Khalak et al., 2020; Kovalenko et al., 2020).

The obtained results of the study may indicate higher biological value of the organic compound of zinc for the organism of rabbits depending on the used amount. From the literature sources, it is known that diets, balanced regarding macro- and microelements without taking into considerateon their biological availability, do not have an expected effect on the biochemical and productive indicators of the animals` organisms, especially rabbits, which are characterized by the highest growth parameters among mammals (De Blas \& Wiseman, 2010). In the blood of rabbits, the activity of aspartate aminotransferase is insignificant and less expressed compared with alanine aminotransferase in contrast to carnivorous animals, which is associated with the peculiarity of functioning of their organism (Mandal et al., 2008). The abovementioned changes in the activity of these amino transferases were confirmed in our studies.

Watering rabbits with different amounts of zinc citrate during 36 days of the study positively affected the indicators of lipid metabolism in the young animals, manifested in the content of cholesterol in blood of rabbits of the I, II and III and triacylglycerols in the II and III studied groups. This may indicate the selective periodic effect which depends on the amount of zinc citrate applied in the diet of young rabbits. The level of creatinine in the studied group underwent no reliable changes compared with the con- trol group, which is a positive effect. The final product of metabolism creatin-creatinine - accumulates in the kidneys, synthesized in these organs from amino acids: arginine, glycine, methionine (Gutyj et al., 2019).

The content of lipid hydroperoxides was reliably lower during prolonged (36 days of providing the supplement) intake of zinc citrate in all the studied groups, determining the positive effect of zinc in the form of nanocompounds. Free-radical peroxidation practically in all stages of its course forms a number of products which are the result of interaction of free-radicals, as well as biological macromolecules. Therefore, during peroxidation of lipids with active forms of oxygen, other active radicals form (peroxides, epoxides, aldehydes, ketons, alcohols, dialdehydes) which can covalently interact with separately functional groups of proteins, leading to destruction of their amino acid residues (Boyko et al., 2016; Kisera et al., 2019). All this may cause modification of the phospholipid bilayer of cellular markers, particularly emergence of oxidation products in the hydrophobic region, which initiate the processes of ionic transport, change in the conformational isomerism of protein and lipid composition, and from there the structural and functional properties of membranes (Kulyaba et al., 2019; Grymak et al., 2020).

Activation of the processes of peroxidation of lipids in the organism of rabbits is a consequence of the effect of microelement compounds on the living organism, the result of oxidation catabolism of complex organic structures. The phases of anxiety and reaction of the organism to the introduction of the compound of microelement correspond to the activation of peroxidation of lipids in the organs and tissues, and the phases of adaptation were characterized by reduced level of peroxidation. At the same time, on the 36th day, in all the groups, zinc citrate caused decrease in the level of products of lipid peroxidation in the blood of rabbits.

Protection against active forms of oxygen is based mainly on their effective elimination. In these processes, enzymes of the antioxidant system participate, particularly superoxide dismutase, catalase and peroxidases (Gutyj et al., 2017). Because, superoxide dismutase utilizes active forms of oxygen with the formation of $\mathrm{H}_{2} \mathrm{O}_{2}$, achieving balance between its activity and $\mathrm{H}_{2} \mathrm{O}_{2}$-oxidizing catalase is important for the vitality of the cell. Catalase converts $\mathrm{H}_{2} \mathrm{O}_{2}$ to water. The active center of enzyme includes threevalent ferum, protoporphyrin which interacts with hydrogen peroxide 
through catalase or peroxidase mechanism, depending on the concentration of substrate (Gutyj et al., 2016).

In the blood of rabbits of the II and II experimental groups, the activity of catalases increased as well as the activity of glutathione reductase in I, II and III groups on the 12th day of intake of the zinc citrate supplement, compared with the control. The obtained results indicate the stimulating effect of zinc prepared using nanotechnologies and activation of metabolism of antioxidant enzymes in the organism of rabbits (catalase and glutathione reductase are protective enzymes which prevent excessive formation of active forms of oxygen and take part in non-radical decomposition of lipid peroxides). In total, the action of all protective enzymes focuses on decrease in the concentration of cytotoxic hydroxyl radicals (Ivanišinová et al., 2016). The main antioxidant in the organism is restored glutathione. Apart from inactivation of lipid hydroperoxides in an enzymic way, glutathione inhibits active forms of oxygen in a non-enzymic way and simultaneously oxidizes thiol groups, first of all glutathione to disulfides. The rate of this reaction depends on the concentration of glutathione in the cell, during decrease in this concentration content of hydrogen peroxide increases, as well as the concentration of cytotoxic free radicals. For the regeneration of glutathione, cells contain glutathione reductase (Saleh et al., 2018).

In the organism of rabbits, calcium digests well with fodder, and its excesses are removed with urine. It is much more complicated with phosphorus in the diet of rabbits. The mechanisms of digestion of phosphorus in the organism of rabbits remain completely undetermined. In most species of mammals, non-organic phosphorus is absorbed from the duodenum and the small intestine and is regulated by the endocrine system. Research has determined the existence of active mechanism of transport of phosphorus from the duodenum and the proximal small intestine in 3-month old rabbits. The absorption of phosphorus in young animals is very likely to be more active than in adults. Our studies revealed the influence of compound of zinc citrate on the activation of processes of digestion of phosphorus in the organism of rabbits after weaning, as confirmed by young animals subjected to the influence of nanoaquachelate of the microelement (Ivanitskaya et al., 2019). An important indicator of balanced diet of animals, especially fast-growing young rabbits, is the ratio of calcium and phosphorus in their organism. As is known, the optimal ratio of calcium and phosphorus must be within the range of 1.5-2.0:1.

The results of growth of rabbits according to the periods of the study showed the activating effect of larger amount of zinc citrate on the digestion of zinc in the organism, which contributed to better transformation of nutrients of feed in the production of rabbit breeding and manifested in higher growth parameters of rabbits of the III experimental group during the study compared with the control.

\section{Conclusions}

Additional watering of rabbits after weaning with zinc citrate manufactured using nanotechnologies in the amount of $0.25 \mathrm{mg}$ of $\mathrm{Zn} / \mathrm{kg}$ of body weight led to its physiological effect on the biochemical parameters of their organism, manifested by reliably higher level of the total protein on the 12th and 36th days, increase in the activity of glutathione reductase on the 12th day, ALAT on the 24th day and catalase and alkaline phosphatase on the 36th day of the survey and decrease in the level of cholesterol on the 24th day and lipid hydroperoxides on the 36th day of the survey compared with the control. After intake of zinc citrate in the amount of $0.50 \mathrm{mg}$ of $\mathrm{Zn} / \mathrm{kg}$ of body weight, in the blood of rabbits, there were seen a reliable increase in the activities of catalase and glutathione reductase on the 12th day, lower level of lipid hydroperoxides on the 36th day and increased parameters of growth of the organism by $3.1 \%$ at the final period of the survey as compared with the control. Use of zinc citrate in the amount of $0.75 \mathrm{mg}$ of $\mathrm{Zn} / \mathrm{kg}$ of body weight in the diet of rabbits manifested in their blood by probable decrease in the level of cholesterol and triacylglycerols and increases in catalase and glutathione reductase on the 24th day, heightened activity of alanine amino transferase and decrease in lipid hydroperoxides on the 36th day of the experiment, which caused a stimulating effect on the growth of the organism with $8.4 \%$ higher total increment of body weight at the conclusion of the experiment.

\section{References}

Albanese, A., Tang, P. S., \& Chan, W. C. (2012). The effect of nanoparticle size, shape, and surface chemistry on biological systems. Annual Review of Biomedical Engineering, 14, 1-16.

Amen, M. H. M., \& Daraji, H. J. A. (2011). Influence of dietary supplementation with zinc on sex hormones concentrations of broiler breeder chickens. Pakistan Journal of Nutrition, 10(11), 1089-1093.

Boyko, O. O., Zazharska, N. M., \& Brygadyrenko, V. V. (2016). The influence of the extent of infestation by helminths upon changes in body weight of sheep in Ukraine. Visnyk of Dnipropetrovsk University, Biology, Ecology, 24(1), 3-7.

Darmohray, L. M., Luchyn, I. S., Gutyj, B. V., Golovach, P. I., Zhelavskyi, M. M., Paskevych, G. A., \& Vishchur, V. Y. (2019). Trace elements transformation in young rabbit muscles. Ukrainian Journal of Ecology, 9(4), 616-621.

De Blas, C., \& Wiseman, J. (2010). Nutrition of the Rabbit. 2nd edition. Library of Congress Cataloging-in-Publication Data. CABI is a trading name of CAB International.

Grosskopf, H. M., Schwertz, C. I., Machado, G., Bottari, N. B., da Silva, E. S., Gabriel, M. E., Lucca, N. J., Alves, M. S., Schetinger, M. R. C., Morsch, V. M., Mendes, R. E., \& da Silva, A. S. (2017). Cattle naturally infected by Eurytrema coelomaticum: Relation between adenosine deaminase activity and zinc levels. Research in Veterinary Science, 110, 79-84.

Grymak, Y., Skoromna, O., Stadnytska, O., Sobolev, O., Gutyj, B., Shalovylo, S., Hachak, Y., Grabovska, O., Bushueva, I., Denys, G., Hudyma, V., Pakholkiv, N., Jarochovich, I., Nahimiak, T., Pavliv, O., Farionik, T., \& Bratyuk, V. (2020). Influence of "Thireomagnile" and "Thyrioton" preparations on the antioxidant status of pregnant cows. Ukrainian Journal of Ecology, 10(1), 122-126.

Gutyj, B. V., Murs'ka, S. D., Gufrij, D. F., Hariv, I. I., Levkivs'ka, N. D., Nazaruk, N. V., Gajdjuk, M. B., Pryjma, O. B., Bilyk, O. J., \& Guta, Z. A. (2016). Vplyv kadmiievoho navantazhennia na systemu antyoksydantnoho zakhystu orhanizmu buhaitsiv [Influence of cadmium loading on the state of the antioxidant system in the organism of bulls]. Visnyk of Dnipropetrovsk University, Biology, Ecology, 24(1), 96-102.

Gutyj, B. V., Ostapyuk, A. Y., Sobolev, O. I., Vishchur, V. J., Gubash, O. P., Kurtyak, B. M, Kovalskyi, Y. V., Darmohray, L. M., Hunchak, A. V., Tsisaryk, O. Y., Shcherbatyy, A. R., Farionik, T. V., Savchuk, L. B., Palyadichuk, O. R., \& Hrymak, K. (2019). Cadmium burden impact on morphological and biochemical blood indicators of poultry. Ukrainian Journal of Ecology, 9(1), 236-239.

Gutyj, B., Stybel, V., Darmohray, L., Lavryshyn, Y., Turko, I., Hachak, Y., Shcherbatyy, A., Bushueva, I., Parchenko, V., Kaplaushenko, A., Krushelnytska, O. (2017). Prooxidant-antioxidant balance in the organism of bulls (young cattle) after using cadmium load. Ukrainian Journal of Ecology, 7(4), 589-596.

Han, X. Y., Ma, Y. F., Lv, M. Y., Wu, Z. P., \& Qian, L. C. (2014). Chitosan-zinc chelate improves intestinal structure and mucosal function and decreases apoptosis in ileal mucosal epithelial cells in weaned pigs. British Journal of Nutrition, 111(8), 1405-1411.

Hassan, F. A., Rania, M. M., \& El-Araby, I. E. (2017). Growth performance, serum biochemical, economic evaluation and 16 gene expression in growing rabbits fed diets supplemented with zinc nanoparticles. Zagazig Veterinary Journal Research, 45(3), 238-249.

Ivanišinová, O., Grešáková, L., Ryzner, M., Ocel’ová, V., \& Čobanová, K. (2016). Efects of feed supplementation with various zinc sources on mineral concentration and selected antioxidant indices in tissues and plasma of broiler chickens. Acta Veterinaria Brno, 85(3), 285-291.

Ivanitskaya, A. I., \& Lesyk, Y. V. (2019). The influence of silicium compounds on the content of calcium, phosphorus and some lipides in the plasma blood. Scientific Messenger of Lviv National Universityof Veterinary Medicine and Biotechnologies, Series Veterinary Sciences, 95, 41-46 (in Ukrainian).

Khalak, V., Gutyj, B., Bordun, O., Ilchenko, M., \& Horchanok, A. (2020). Effect of blood serum enzymes on meat qualities of piglet productivity. Ukrainian Journal of Ecology, 10(1), 158-161.

Kisera, Y. V., Storchak, Y. G., Gutyj, B. V., Bozhyk, L. Y., Magrelo, N., Sus, Y., Dashkovskyy, O., Pryimych, V. I., Vus, U., Kit, L., \& Sachuk, R. (2019). Structural and functional features of the vermiform appendix at the tissue and cellular levels in rabbits after the introduction of immunobiological drugs. Ukrainian Journal of Ecology, 9(2), 217-226.

Kovalenko, A. M., Tkachev, A. V., Tkacheva, O. L., Gutyj, B. V., Prystupa, O. I., Kukhtyn, M. D., Dutka, V. R., Veres, Y. M., Dashkovskyy, O. O., Senechyn, V. V., Riy, M. B., \& Kotelevych, V. A. (2020). Analgesic effectiveness of new nanosilver drug. Ukrainian Journal of Ecology, 10(1), 300-306.

Kulyaba, O., Stybel, V., Gutyj, B., Turko, I., Peleno, R., Turko, Y., Golovach, P., Vishchur, V., Prijma, O., Mazur, I., Dutka, V., Todoriuk, V., Golub, O., Dmytriv, O., \& Oseredchuk, R. (2019). Effect of experimental fascioliasis on the protein synthesis function of cow liver. Ukrainian Journal of Ecology, 9(4), 612-615.

Lesyk, Y., Ivanytska, A., Kovalchuk, I., Monastyrska, S., Hoivanovych, N., Gutyj, B., Zhelavskyi, M., Hulai, O., Midyk, S., Yakubchak, O., \& Poltavchenko, T. (2020). Hematological parameters and content of lipids in tissues of the orga- 
nism of rabbits according to the silicon connection. Ukrainian Journal of Ecology, 10(1), 15-22.

Mandal, G. P., Dass, R. S., Garg, A. K., Varshney, V. P., \& Mondal, A. B. (2008) Effect of zinc supplementation from inorganic and organic sources on growth and blood biochemical profile in crossbred calves. Journal of Animal and Feed Sciences, 17(2), 147-156.

Mateos, G. G., Rebollar, P. G., \& de Blas, C. (2010). Minerals, vitamins and additives. The nutrition of the rabbit. CABI Publishing, Wallingford, 119-150.

Nessrin, S., Abdel-Khalek, A. M., \& Gad, S. M. (2012). Effect of supplemental zinc, magnesium or iron on performance and some physiological traits of growing rabbits. Asian Journal of Poultry Science, 6(1), 23-30.

Raguvaran, R., Manuja, A., \& Manuj, B. K. (2015). Zinc oxide nanoparticles: Opportunities and challenges in veterinary sciences. Immunome Research, 11(2), 2-8.

Saleh, A. A., Ragab, M. M., Ahmed, E. A. M., Abudabos, A. M., \& Ebeid, T. A (2018). Effect of dietary zinc-methionine supplementation on growth performance, nutrient utilization, antioxidative properties and immune response in broiler chickens under high ambient temperature. Journal of Applied Animal Research, 46(1), 820-827.
Sri Sindhura, K., Prasad, T. N. V. K. V., Selvam, P. P., \& Hussain, O. M. (2014) Synthesis, characterization and evaluation of effect of phytogenic zinc nanoparticles on soil exo-enzymes. Applied Nanoscience, 4(7), 819-827.

Swain, P. S., Rajendran, D., Rao, S. B. N., \& Dominic, G. (2015). Preparation and effects of nano mineral particle feeding in livestock: A review. Veterinary World, 8(7), 888-891.

Swain, P. S., Rao, S. B., Rajendran, D., Dominic, G., \& Selvaraju, S. (2016). Nano zinc, an alternative to conventional zinc as animal feed supplement: A review. Animal Nutrition, 2(3), 134-141.

Tsai, Y. H., Mao, S. Y., Huang, M. Z., \& Lien, T. F. (2016). Effects of nanosize zinc oxide on zinc retention, eggshell quality, immune response and serum parameters of aged laying hens. Animal Feed Science and Technology, 213, 99-107.

Vlislo, V. V. (2012) Laboratorni metody doslidzhen u biolohii, tvarynnytstvi ta veterynarniy medytsyni [Laboratory methods of research in biology, animal husbandry and veterinary medicine]. Spolom, Lviv (in Ukrainian).

Wang, K. K., Cui, H. W., Sun, J. Y., Qian, L. C., \& Weng, X. (2012). Effects of zinc on growth performance and biochemical parameters of piglets. Turkish Journal of Veterinary and Animal Sciences, 36(5), 519-526. 